\title{
Successful therapy in unusual generalized Dermatophilus congolensis infection in a calf based on modified in vitro disk diffusion test
}

\section{Sucesso no tratamento de infecção generalizada em bezerra por Dermatophilus congolensis baseado em teste in vitro modificado de difusão com discos}

\author{
Paulo Francisco Domingues', Simony Trevizan Guerra1 *, Carolina Lechinski de Paula', \\ Ana Carolina Alves ${ }^{1}$, Carmen Alicia Daza Bolanos ${ }^{1}$, Amanda Bonalume Cordeiro de Morais ${ }^{1}$, \\ Rafaela Mastrangelo Risseti', Bruna da Silva Colhado', Fábio Vinicius Ramos Portilho', Marília \\ Salgado Caxito', Fernando José Paganini Listoni' ${ }^{1}$, Daniel Ornelas de Oliveira', Márcio Garcia Ribeiro'
}

\begin{abstract}
Bovine dermatophilosis is a dermatitis characterized by typical focal or localized lesions with "paintbrush" aspect and occasionally as disseminated cutaneous disease. We report the case of a one-year-old Nelore female with history of chronic cutaneous disseminated lesions that appeared immediately after a rainfall period. Serous to purulent exudates, hair with tufted appearance, hyperkeratotic, nonpruritic, hardened, yellowish to brown, and coalescent crusty lesions were observed distributed all over its body. Removal of the crusts revealed ulcerated or hemorrhagic areas, with irregular elevated crusts like "paintbrush". Microbiological diagnosis enabled the identification of a microorganism, the Dermatophilus congolensis. Despite disseminated and chronic lesions, we obtained a successful therapy with parenteral therapy using long-acting tetracycline based on modified in vitro disk diffusion test. The present report highlights success therapy in uncommon generalized bovine dermatophilosis with selection of first-choice drugs based on modified in vitro susceptibility test, and need of responsible use of antimicrobials in livestock.
\end{abstract}

KEYWORDS: dermatophilosis; bovine; treatment; in vitro susceptibility pattern; oxytetracycline.
RESUMO: A dermatofilose bovina é uma dermatite caracterizada por lesōes focais ou localizadas com aspecto de "pincel" e, ocasionalmente, como lesão cutânea disseminada. Relata-se o caso de uma fêmea bovina de um ano de idade, que foi atendida apresentando história de lesôes cutâneas crônicas imediatamente após um período de alta pluviosidade. Ao exame clínico, lesões serosas a purulentas, com hiperqueratose, coalescentes, não pruriginosas, ressecadas, de coloração amarelada à acinzentada foram observadas distribuídas de modo generalizado pelo animal. A remoção das crostas revelou áreas ulceradas ou hemorrágicas, com crostas irregulares e elevadas semelhantes a "pincel". O diagnóstico microbiológico possibilitou a identificação do micro-organismo Dermatophilus congolensis. Apesar das lesôes disseminadas e crônicas, a cura do animal foi obtida com tratamento parenteral usando oxitetraciclina de longa duração, baseado em teste in vitro de sensibilidade microbiana modificado. O presente relato ressalta o sucesso no tratamento de caso incomum de lesóes generalizadas de dermatofilose bovina com respaldo de teste in vitro de sensibilidade modificado, bem como a necessidade do uso responsável de antimicrobianos em animais de produção.

PALAVRAS-CHAVE: dermatofilose; bovinos; tratamento; teste de sensibilidade microbiana in vitro; oxitetraciclina. 
Dermatophilus congolensis (D. congolensis) is a well-recognized Gram-positive, non-acid-fast, branching filamentous rod (cocci). These microorganisms are facultative anaerobic, capnophilic or aerobic tolerant bacteria that belong to the Actinomycetales order (QUINN et al., 2011). The pathogen causes exudative dermatitis affecting mainly livestock, occasionally companion animals (GREENE, 2007; NATH et al., 2010; DALIS et al., 2014) and wildlife, and rarely humans (ZARIA, 1993; BURD et al., 2007). It is an atypical bacterium, because it produces infective motile zoospores and aerial mycelia (SONGER; POST, 2005; GIUFFRIDA, 2016).

The natural habitat of the organism is controversial (MARSELLA, 2014), although it is a normal inhabitant of the livestock skin (RADOSTITS et al., 2007). It is also found in water, organic material, and in the environment of livestock farms (ZARIA, 1993). Direct transmission occurs by means of zoospores from the skin, contact between carrier or sick and susceptible animals. High and long rainfall and warm temperatures reduce the normal superficial protective factors of the skin and predispose animals to clinical lesions (OJONG et al., 2016). In addition, contamination of puncture wounds and utensils, flies and tick bites, and face and limb lesions caused by pointed-tip pasture (Brachiaria sp.) may predispose animals to indirect infection. Microenvironmental conditions (temperature, humidity) may lead to the activation of dormant skin zoospores, producing germ tubes containing active multi-flagellated zoospores that invade the epidermis. Cutaneous lesions are determined by a cyclical pattern of invasion, epidermis inflammation, serous exudation, and micro abscesses, followed by regeneration that result in the formation of scabs and crusts containing the pathogen (NATH et al., 2010).

The cutaneous virulence of $D$. congolensis is intimately associated with the ability of the strains to produce alkaline ceramidase, phospholipases, proteolytic enzymes, and hemolysins (NORRIS et al., 2008; GIUFFRIDA, 2016). Geographical variation of isolate-to-isolate related to genetic diversity has been observed among $D$. congolensis obtained from livestock of different countries and in regions of the same country (SONGER; POST, 2005; MARSELLA, 2014).

Clinical dermatophilosis is more prevalent in tropical and subtropical countries. Early lesions consist of papules that evolve to serous exudates, hair with tufted appearance, hyperkeratotic, non-pruritic, hardened, and coalescent lesions with irregular elevated crust that are like "paintbrush" lesions (ZARIA, 1993). Typically, tufts of hair are easily removed from the lesions. Removal of the crusty lesions reveals erythematous, ulcerated, or hemorrhagic areas. Focal lesions in the body are the most common lesions. The outcome of disease is usually benign, considering that animals rarely show disseminated or extensive lesions with systemic signs, including difficulty to eat, loss of body condition, and depression, especially in oral lesions (QUINN et al., 2011). In tropical areas, animals in whose lesions of diseases have already regressed are repeatedly re-infected in successive wet periods, characterizing endemic regions (OJONG et al., 2016).

Routine diagnosis is based on the history of predisposing factors, suggestive cutaneous clinical signs, cytological identification of typical aspects of the pathogen in crusts, and microbiological culture and isolation of $D$. congolensis from lesions (SONGER; POST, 2005; GIUFFRIDA, 2016).

A wide variety of topical and parenteral antimicrobials (monotherapy or combined use) has been recommended for treatment, although topical procedure is recognized as largely ineffective and some conventional drugs do not reach epidermal therapeutic concentrations (BURD et al., 2007). In addition, treatment outcome is influenced by severity and extent of lesions (QUINN et al., 2011), since disseminated lesions are generally refractory to therapy. Commonly, penicillin, streptomycin, and/or tetracyclines are the antimicrobials of choice for parenteral therapy of dermatophilosis (RADOSTITS et al., 2007). However, there is no standard procedure for in vitro antimicrobial susceptibility tests for some coryneform bacteria or actinomycetes (Clinical and Laboratory Standards Institute - CLSI, 2014), including D. congolensis. We report the effective therapy of an unusual generalized Dermatophilus congolensis infection in a female calve and the selection of firstchoice antimicrobials based on modified in vitro disk diffusion method in this case report.

A one-year-old Nelore female was seen at end of November 2014 with history of chronic cutaneous lesions immediately after a rainfall period. The animal came from Anhembi, in the center region of the state of São Paulo, Brazil. This city is located 469 meters above sea level (latitude of $22^{\circ} 48^{\prime} 22$ South and longitude of $48^{\circ} 07^{\prime}$ 'West coordinates), and it is characterized by humid subtropical climate, where bovine breeding is common. The owner mentioned no report of similar disease in this region. In addition, the animal was from a herd of other 40 bovines born in the same farm, of different ages, but only such animal showed clinical signs of cutaneous chronic disease (about four months prior this paper conclusion). The herd was raised on Brachiaria sp. pasture. At clinical examination, serous to purulent exudates, hair with tufted appearance, hyperkeratotic, non-pruritic, hardened, yellowish to brown, and coalescent crusty lesions of about 2.5 in diameter were observed distributed all over the body (Fig. 1). Removal of the crusts revealed ulcerated or hemorrhagic areas, with irregular elevated crusts, which are like a "paintbrush". Tufts of hair in the lesions were easily removed, leading to preliminary diagnosis of dermatophilosis. At clinical examination, the animal presented normal body condition, as well as presence of ticks.

Crust samples were manually collected from all over the animal's body using plastic gloves. Samples were kept refrigerated $\left(4-8^{\circ} \mathrm{C}\right)$ and immediately sent to the Laboratory of 
Microbiology at the School of Veterinary Medicine and Animal Sciences of Universidade Estadual Paulista "Júlio de Mesquita Filho" (FMVZ-UNESP), in Botucatu, state of São Paulo, Brazil. Then, we macerated fragments of the samples with saline solution $(0.85 \%)$ in a laminar flow hood. Crust samples were plated simultaneously on defibrinated sheep blood agar (5\%) and MacConkey agar, and incubated aerobically at $37^{\circ} \mathrm{C}$ for 72 hours. The same samples were plated on sheep blood agar (5\%), in $5 \% \mathrm{CO}_{2}$ at $37^{\circ} \mathrm{C}$ for 96 hours. We identified the microorganism based on conventional phenotypic methods, including catalase, urease, gelatin, and acid production from glucose, fructose, and maltose (SONGER; POST, 2005; GIUFFRIDA, 2016). Furthermore, crust samples were subjected to direct cytological examination using Gram and Giemsa stains.

We submitted the isolate to the antimicrobial disk diffusion test according to the CLSI guidelines for aerobic bacterium (CLSI, 2014) with some modifications due to the absence of standard protocols and breakpoints regarding interpretative inhibition zones for some coryneform bacteria or actinomycetes (MARTÍNEZ-MARTÍNEZ et al., 1995; RIBEIRO et al., 2015), such as $D$. congolensis. The isolate was cultured on sheep blood agar $(5 \%)$ under aerobic conditions at $37^{\circ} \mathrm{C}$. After 48 hours, pure colonies of the isolate were inoculated in tubes containing brain heart infusion broth $(3 \mathrm{~mL})$ supplemented with $30 \mu \mathrm{L}$ of Tween 80 . Afterwards, the tube was vortexed to decrease clump formation, and incubated at $37^{\circ} \mathrm{C}$ for 48 hours, until the appropriate optical density (OD) was reached in the McFarland scale (AMBAYE et al., 1997; CONDAS et al., 2013). The final inoculum was adjusted to OD equivalent to a $0.5 \mathrm{McF}$ arland standard. We used Streptococcus pneumoniae to define the inhibition zones, based on similar studies involving aerobic actinomycetes (ZASTEMPOWSKA; LASSA, 2012; CONDAS et al., 2013; RIBEIRO et al., 2015). The isolate was classified as susceptible, intermediate or resistant to antimicrobials after 48 hours of incubation. Fifteen commercially available antimicrobials for livestock veterinarian practice and/or indicated (monotherapy or combination therapy) for bovine dermatophilosis were used in vitro, comprising seven different antimicrobial groups, as follows:

- beta-lactams (ceftiofur $30 \mu \mathrm{g}$, penicillin $10 \mathrm{IU}$, ampicillin $10 \mu \mathrm{g}$, ceftriaxone $30 \mu \mathrm{g}$ );

- aminoglycosides (gentamicin $10 \mu \mathrm{g}$, streptomycin $10 \mu$, amikacin $30 \mu \mathrm{g})$;

- amphenicols (florfenicol $30 \mu \mathrm{g}$ );

- fluoroquinolones (enrofloxacin $5 \mu \mathrm{g}$, ciprofloxacin $5 \mu \mathrm{g}$, marbofloxacin $5 \mu \mathrm{g})$;

- macrolides (azithromycin $15 \mu \mathrm{g}$ );

- tetracyclines (oxytetracycline $30 \mu \mathrm{g}$ );

- sulfonamides (trimethoprim/sulfamethoxazole $25 \mu \mathrm{g}$ ).

After 48 hours of incubation, rough, hemolytic, dry, golden-yellow colonies of $1 \mathrm{~mm}$ in diameter and firmly adhered to media were observed on sheep blood agar at the aerobic and $5 \% \mathrm{CO}_{2}$ conditions (Fig. 2A). No microorganisms were observed on the MacConkey agar. Conventional phenotypic tests enabled the classification of the microorganism as Dermatophilus congolensis. Gram and Giemsa-stained smears made from the crusts revealed Gram-positive, branching filamentous organisms with typical "tram-track" appearance (Fig. 2B).

The in vitro antimicrobial susceptibility test revealed that almost all drugs were effective, except penicillin, enrofloxacin, and ciprofloxacin. Based on the in vitro antimicrobial susceptibility profile, the animal was isolated and treated with three intramuscular applications of long-acting tetracycline (oxytetracycline, $20 \mathrm{mg} / \mathrm{kg}$ ) weekly, showing re-epithelialization of the cutaneous lesions after three weeks of therapy (Fig. 3). In addition, we recommended control measures against bovine dermatophilosis to the farm owner, especially to provide shelter
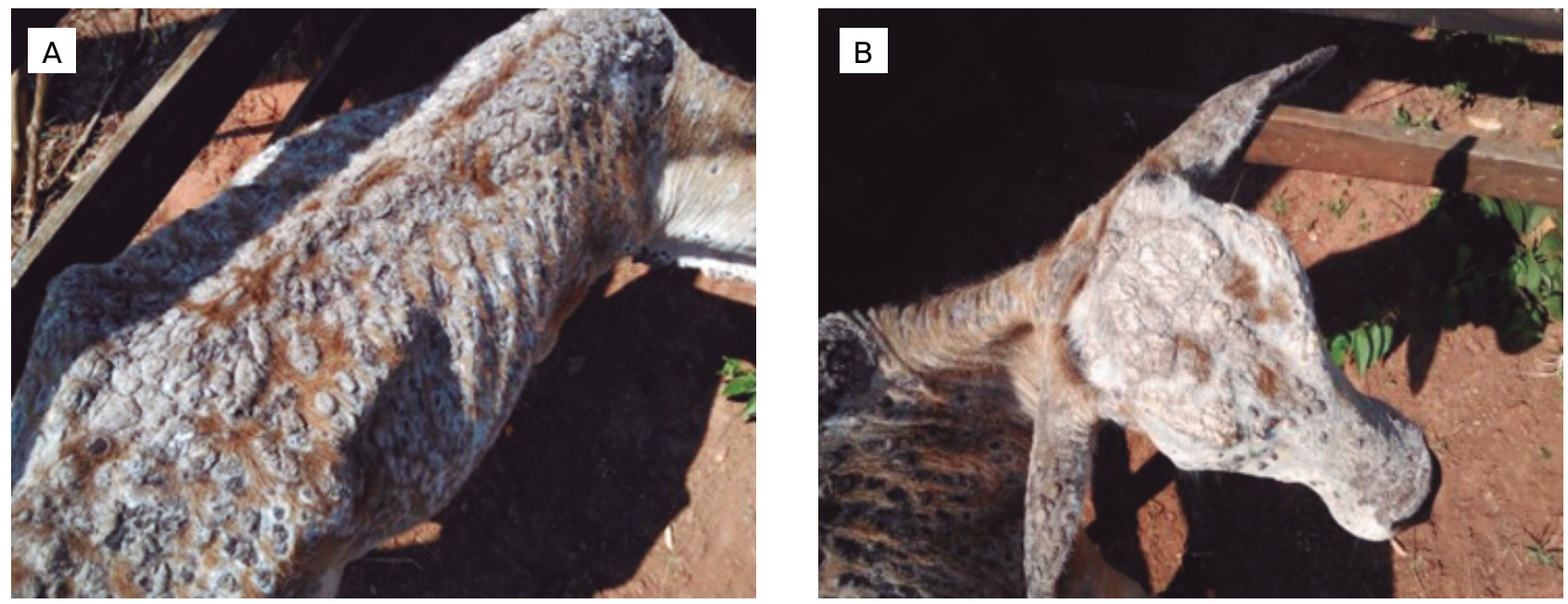

Figure 1. Generalized Dermatophilus congolensis infection in a calf. (A) Serous to purulent exudates, hair with tufted appearance, hyperkeratotic, hardened, yellowish to brown, and coalescent crusty lesions of about 2.5 in diameter distributed all over the body. (B) Detail of the head and neck lesions. Botucatu, SP, Brazil, 2014. 
in long rainfall, to use acaricides for controlling flies and ticks, and to clear grazing areas.

In this report, we described a case of dermatophilosis in a female calf, emphasizing some clinical and epidemiological aspects of the disease, success of therapy in uncommon disseminated cutaneous lesions based on in vitro resistance profile assessed by modified in vitro disk diffusion test, and the importance of responsible use of antimicrobials in livestock.

Generalized D. congolensis infection occurred in the beginning of the summer (after a rainfall period) in the animal we treated, reinforcing the findings of other reports in Brazil (CUNHA et al., 2010; BACHA et al., 2014) and in other countries (ZARIA, 1993; TOPA et al., 2001). Such papers described increased prevalence of the disease among young animals, with seasonal influence of long rainfall periods (QUINN et al., 2011). Hence, two outbreaks of bovine dermatophilosis were described in Brazil affecting approximately 500 Nelore calves kept in Brachiaria brizantha pastures. Animals showed lesions mainly in the face after a rainy period, with high presence of flies (Haematobia irritans).

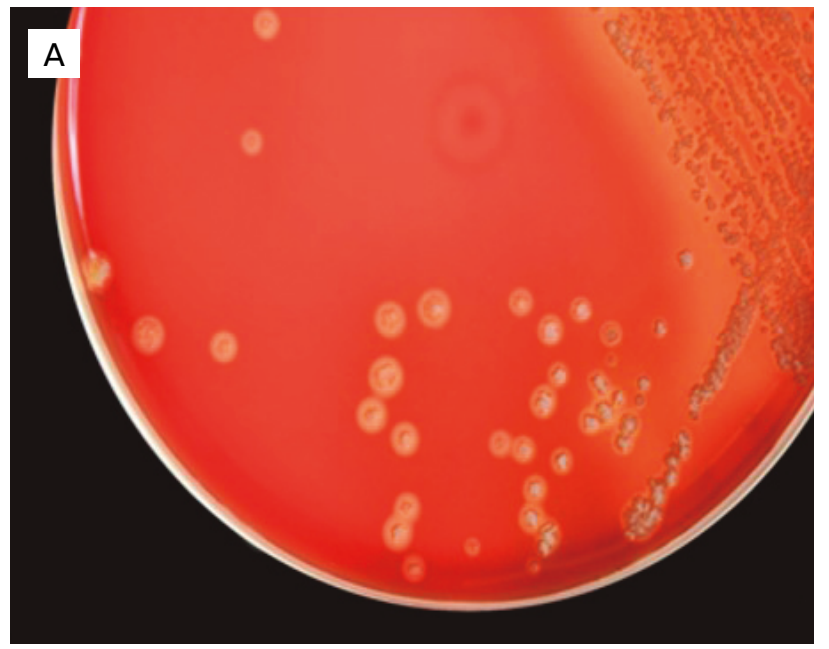

Data from these authors are in agreement with the findings in our report. The calf described was also kept in Brachiaria, and this pasture may cause microlesions in the skin, which may favor D. congolensis infection (BACHA et al., 2014). The animal reported herein presented infestations by ticks that is recognized as a predisposing condition of bovine dermatophilosis (PAL, 1995; OJONG et al., 2016). It could explain, in part, lesions exclusively in this animal, as well as good body condition and contact with other bovines in same farm. In addition, some domestic animals may have a hereditary predisposition to $D$. congolensis infection, which could justify the clinical manifestations in one or few animals when breeding in the same environment or farm (ZARIA, 1993).

$D$. congolensis from different geographical areas can vary in their antimicrobial susceptibility pattern (ZARIA, 1993; PAL, 1995; RADOSTITS et al., 2007); therefore, therapy should be based on in vitro susceptibility tests. In vitro antimicrobial susceptibility tests do no represent a guarantee of cure, although the choice for drugs based on in vitro susceptibility pattern is a predictive factor of better

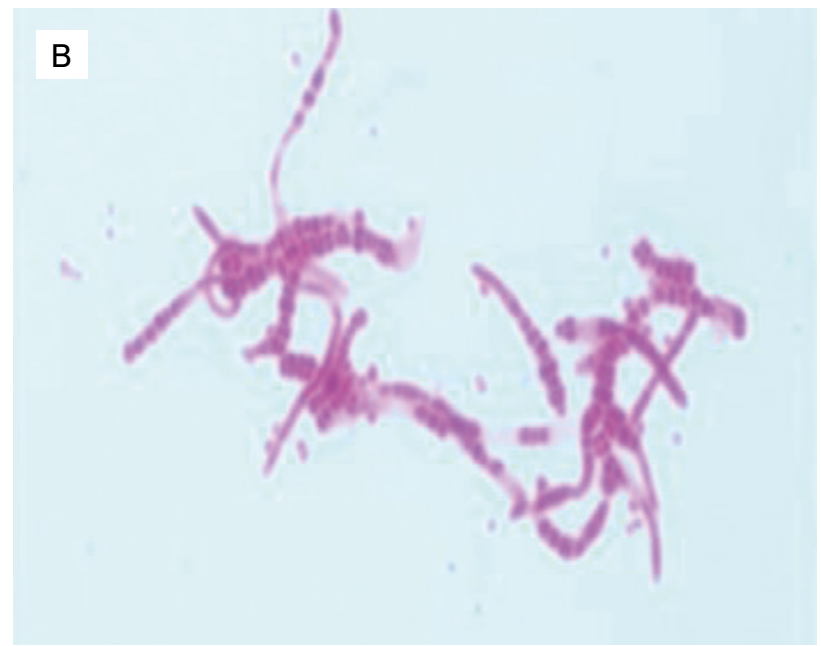

Figure 2. Microbiological diagnosis of bovine dermatophilosis. (A) Rough, hemolytic, dry, golden-yellow colonies of $1 \mathrm{~mm}$ in diameter of Dermatophilus congolensis isolated in defibrinated sheep blood agar at aerobic and $5 \% \mathrm{CO}_{2}$ conditions, after 48 hours of incubation. (B) Gram-positive branching organisms or "tram-track" appearance of Dermatophilus congolensis (Gram staining, 1,000 x). Botucatu, SP, Brazil, 2014.
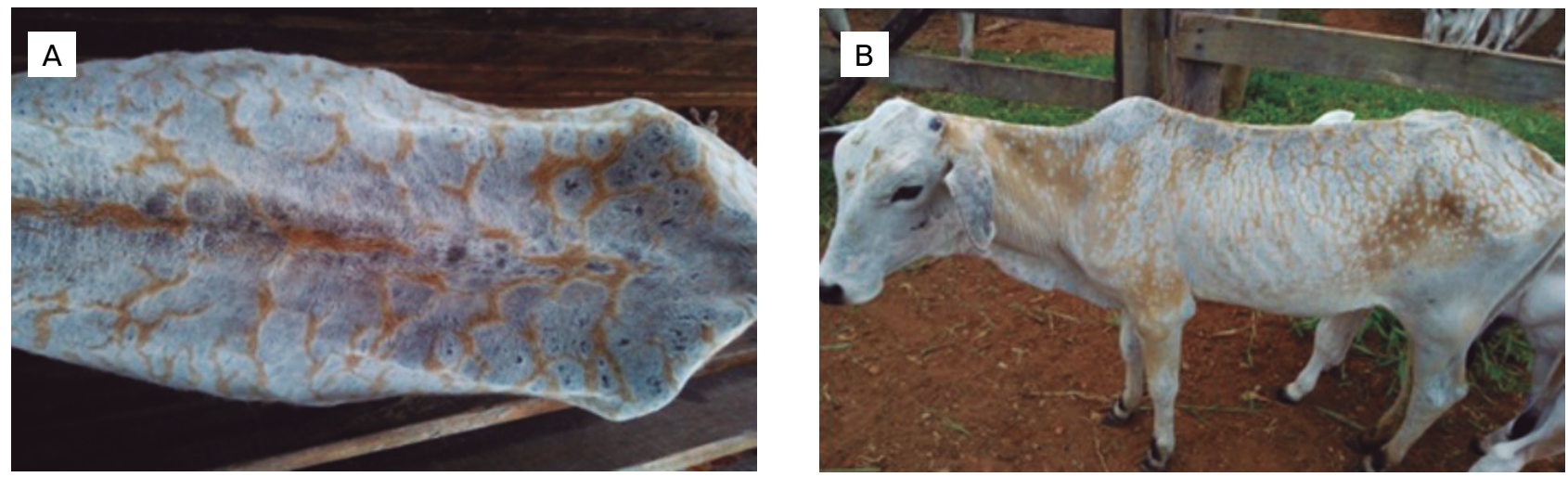

Figure 3. Outcome of generalized cutaneous lesions caused by Dermatophilus congolensis in a calf after three weeks of treatment with oxytetracycline. (A) Detail of animal dorsum showing various round resolved lesions. (B) Aspect of general re-epithelialization of the lesions. Botucatu, SP, Brazil, 2014. 
efficacy of in vivo therapy, and thus avoid empiric or inappropriate use of antimicrobials (GIGUÈRE et al., 2010). However, there are no standard protocols to in vitro antimicrobial susceptibility tests for some coryneform bacteria or actinomycetes (CLSI, 2014), including D. congolensis. In this scenario, we carried out a modified in vitro disk diffusion method in the present report to determine antimicrobial sensitivity pattern of D. congolensis isolate. Initially, we added some detergent (Tween 80) to the Brain Heart Infusion (BHI) inoculum and tube immediately vortexed to decrease clump formation, which is commonly observed during actinomycetes growth (QUINN et al., 2011). This procedure is necessary to inoculate the appropriate amount of colony forming units $(\mathrm{CFU} / \mathrm{mL})$ of pathogen assessed herein by OD in the McFarland scale, which is considered a critical step to in vitro disk diffusion or microdilution tests for actinomycetes or coryneform bacteria (AMBAYE et al., 1997). Finally, due to the lack of standard interpretative breakpoints categories for $D$. congolensis, based on CLSI for some coryneform bacteria of actinomycetes, other fastidious Gram-positive organisms such as Streptococcus pneumoniae have been used to define inhibition zones. Streptococcus pneumoniae has been applied in similar studies involving in vitro susceptibility pattern of Nocardia species (CONDAS et al., 2013) and Trueperella pyogenes (ZASTEMPOWSKA; LASSA, 2012; RIBEIRO et al., 2015) isolated among various livestock infections.

Different protocols for the in vivo treatment of bovine dermatophilosis have been reported, although beta-lactams (penicillin), aminoglycosides (streptomycin), and tetracyclines are reported as the first-line antimicrobials to the treatment of localized cutaneous lesions of dermatophilosis among livestock (GIUFFRIDA, 2016). The repetition of tetracycline $(5 \mathrm{mg} / \mathrm{kg}$ ) weekly until resolution of clinical signs, or one application of long-acting tetracycline or oxytetracycline $(20 \mathrm{mg} / \mathrm{kg})$ have been described as effective. Parenteral penicillin procaine $(22.000 \mathrm{IU} / \mathrm{kg})$ daily for three days has also been reported to yield good results (RADOSTITS et al., 2007). Alternatively, four intramuscular administrations using long-acting oxytetracycline $(20 \mathrm{mg} / \mathrm{kg} / 48-48$ hours) or intramuscular streptomycin ( $5 \mathrm{mg} / \mathrm{kg}, 24-24$ hours) for one week combined with six applications of long-acting tetracycline $(20 \mathrm{mg} / \mathrm{kg} / 72$ 72 hours), plus five administrations of levamizole $(4 \mathrm{mg} / \mathrm{kg}$, 24-24 hours for three days) with seven days of interval were reported as effective on the treatment of feedlot cattle (CUNHA et al., 2010). In addition, the combined use of a single dose of parenteral oxytetracycline $(1,000 \mathrm{mg})$ and streptomycin $(500 \mathrm{mg})$ or penicillin $(600,000 \mathrm{IU})$ associated with streptomycin $(630 \mathrm{mg})$ was effective in an outbreak of bovine dermatophilosis (BACHA et al., 2014). However, outcome of treatment is influenced by severity and extent of $D$. congolensis lesions in bovines (ZARIA, 1993; QUINN et al., 2011). In the current report, three applications of long-acting tetracycline
$(20 \mathrm{mg} / \mathrm{kg}$ ) weekly were effective to solve a case of generalized bovine dermatophilosis with chronic evolution. Besides in vitro effectiveness of oxytetracycline on the isolates, this drug was chosen for therapy due to its commercial availability, low cost, and reduced number of injections required to conclude the treatment.

Tetracycline is a bacteriostatic antimicrobial agent that inhibits protein synthesis, and that was introduced in the veterinary practice in the 1950s. Despite its initial wide spectrum of action and subsequent introduction of a long-acting tetracycline (oxytetracycline), the use of this antimicrobial has been recently restricted to only some microorganisms because of the increased rates of pathogen resistance to this drug (GIGUÈRE et al., 2010). However, efficacy of oxytetracycline in the present report may be credited to the use of this drug based on the in vitro susceptibility pattern, as non judicious use of antimicrobials is associated with unsuccessful therapy (ANDRADE; GIUFFRIDA, 2008). Inappropriate or empiric use of antibiotics and chemotherapeutic drugs increases rates of multidrug resistant bacteria. In fact, multidrug resistance of bacterial species is an emergent global threat (GIGUÈRE et al., 2010). Based on these data, the selection of first-line antimicrobial therapy should be strongly based on regional in vitro resistance patterns, because the responsible use of antimicrobials for animals is an emergent "One Health" concern (RIBEIRO et al., 2015) to preserve the use of these drugs for human therapy approaches.

There are no specific measures to control the bovine dermatophilosis (RADOSTITS et al., 2007). Considering the disease prevalence is intimately associated with climate conditions and some geographical areas, control measures are based on prompt treatment of affected animals, as well as on minimizing predisposing conditions to the disease. Thus, various general measures are recommended to control the bovine dermatophilosis, such as:

- isolation of affected animals during treatment;

- provision of shelter in long rainfall periods;

- control of flies and ticks using acaricides (spray or dipping);

- clear of grazing areas with pointed-tip pastures;

- control of intercurrent diseases or immunocompromised factors (ZARIA, 1993).

D. congolensis infections in humans are a rare clinical condition and usually self-limiting (BURD et al., 2007). People are commonly infected by $D$. congolensis accidently due to secondary exposure of infected animals or contaminated materials (PAL, 1995), as only about 15 well-described human cases have been reported worldwide (GIUFFRIDA, 2016). Human dermatophilosis is characterized by dermal papules and pustules, folliculitis, subcutaneous nodules, and loss of hair, mainly in the hands, arms and foot (TOWERSEY et al., 1993; PAL, 1995; BURD et al., 2007). However, despite the benign outcome of human dermatophilosis, it is important to 
avoid direct contact with suspected lesions in livestock, especially from endemic areas (GIUFFRIDA, 2016).

We described the successful antimicrobial therapy in an unusual case of generalized bovine dermatophilosis. The antimicrobial susceptibility pattern was assessed by a modified in vitro disk diffusion method, since there are no standard protocols to antimicrobial susceptibility tests for some coryneform bacteria or actinomycetes. In addition, we emphasize the importance of the responsible use of antimicrobials, as well as the selection of first-choice drugs based on regional in vitro resistance profile to improve the rates of success in therapy protocols against the $D$. congolensis infections.

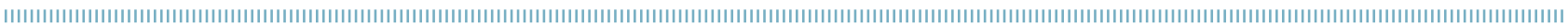
REFERENCES

AMBAYE, A.; KOHNER, P.C.; WOLLAN, P.C.; ROBERTS, G.D.; ROBERTS, K.L.; COCKERILL, F.R. Comparison of agar dilution, broth microdilution, disk diffusion, E-test, and Bactec radiometric methods for antimicrobial susceptibility testing of clinical isolates of the Nocardia asteroides complex. Journal of Clinical Microbiology, v.35, p.847-852, 1997.

ANDRADE, S.F.; GIUFFRIDA, R. Quimioterápicos antimicrobianos e antibióticos. In: ANDRADE, S.F. (Ed.). Manual de Terapêutica Veterinária. São Paulo: Roca, 2008. p.25-72.

BACHA, F.B.; FACCIN, T.C.; LIMA, S.C.; LEAL, C.R.B.; LEMOS, R.A.A. Dermatofilose em bezerros da raça Nelore no Mato Grosso do Sul. Semina: Ciências Agrárias, v.35, n.4, p. 1947-1954, 2014.

BURD, E.M.; JUZYCH, L.A.; RUDRIK, J.T.; HABIB, F. Pustular dermatitis caused by Dermatophilus congolensis. Journal of Clinical Microbiology, v.45, n.5, p.1655-1658, 2007.

CLINICAL AND LABORATORY STANDARDS INSTITUTE (CLSI). Performance standards for antimicrobial susceptibility testing. Twenty-fourth information Supplement. CLSI, 2014.

CONDAS, L.A.; RIBEIRO, M.G.; YAZAWA, K.; DE VARGAS, A.P.; SALERNO, T.; GIUFFRIDA, R.; LANGONI, H.; MELVILLE, P.A.; BIESDORF, S.; MATSUZAWA, T.; GONOI, T.; KASTELIC, J.P.; BARKEMA, H.W. Molecular identification and antimicrobial susceptibility of Nocardia spp. isolated from bovine mastitis in Brazil. Veterinary Microbiology, v. 167, p.708-712, 2013.

CUNHA, P.H.J.; SIQUEIRA, A.K.; OLIVEIRA FILHO, J.P.; BADIAL, P.R.; OLIVEIRA, A.P.; LISTONI, F.J.P.; RIBEIRO, M.G.; BORGES, A.S. Dermatofilose em bovinos criados em regime de confinamento. Veterinária e Zootecnia, v. 17, n.2, p.224-228, 2010.

DALIS, J.S.; KAZEEM, H.M.; KWAGA, J.K.P.; KWANASHIE, C.N. Severe generalized skin lesions due to mixed infection with Sporothrix schenkii and Dermatophilus congolensis in a bull from Jos, Nigeria. Veterinary Microbiology, v. 172, p.475-478, 2014.

GIGUĖRE, S.; PRESCOTT, J.F.; BAGGOT, J.D.; WALKER, R.D.; DOWLING, P.M. Terapia Antimicrobiana em Medicina Veterinária. 4. ed. São Paulo: Roca, 2010. 683p.

GIUFFRIDA, R. Dermatofilose. In: MEGID, J.; RIBEIRO, M.G.; PAES, A.C. (Eds.). Doenças Infecciosas em Animais de Produção e de Companhia. Rio de Janeiro: Roca, 2016. p.81-86.
GREENE, C.E. Dermatophilosis. In: Infectious Diseases of Dogs and Cats. 4. ed. St. Louis, Missouri: Elsevier Saunders, 2007. p.521-523.

MARSELLA, R. Dermatophilosis. In: Equine Infectious Diseases. St. Louis, Missouri: Elsevier, 2014. p.283-286.

MARTÍNEZ-MARTÍNEZ, L.; ORTEGA, M.C.; SUÁREZ, A.I. Comparison of E-test with broth microdilution and disk diffusion for susceptibility testing of coryneform bacteria. Journal of Clinical Microbiology, v.33, p.1318-1321, 1995.

NATH, B.D.; AHASAN, S.; RAHMAN, S.; HUQUE, F. Prevalence and therapeutic management of bovine dermatophilosis. Bangladesh Research Publications Journal, v.4, n.3, p. 198-207, 2010.

NORRIS, B.J.; COLDITZ, I.G.; DIXON, T.J. Fleece rot and dermatophilosis in sheep. Veterinary Microbiology, v. 128, p.217-230, 2008.

OJONG, B.W.; SACCÀ, E.; BESSONG, P.; PIASENTIER, E. Prevalence of bovine dermatophilosis and disease-associated alleles in zebu Goudali cattle and their Italian Simmental crosses ranching in the western highland plateau savannah of Cameroon. Tropical Animal Health Production, v.48, p.1329-1335, 2016.

PAL, M. Prevalence in India of Dermatophilus congolensis infection in clinical specimens from animals and humans. Revue Scientifique et Technique International Office of Epizootics, v. 14, n.3, p.857-863, 1995.

QUINN, P.J.; MARKEY, B.K.; CARTER, M.E.; DONNELLY, W.J.; LEONARD, F.C. Microbiologia Veterinária e Doenças Infecciosas. Porto Alegre: Artmed, 201 1. p.196-206.

RADOSTITS, O.M.; GAY, C.C.; BLOOD, D.C.; HINCHCLIFF, K.W. Veterinary medicine: a textbook of diseases of cattle, horses, sheep, pigs, and goats. 10. ed. Philadelphia: Saunders, 2007. 2156p.

RIBEIRO, M.G.; RISSETI, R.M.; BOLAÑOS, C.A.D.; CAFFARO, K.A.; MORAIS, A.B.C.; LARA, G.H.B.; ZAMPROGNA, T.O.; PAES, A.C.; LISTONI, F.J.P.; FRANCO, M.M.J. Trueperella pyogenes multispecies infections in domestic animals: a retrospective study of 144 cases (2002-2012). Veterinary Quarterly, v.35, p.82-87, 2015.

SONGER, J.G.; POST, K.W. Veterinary microbiology: Bacterial and Fungal agents of Animal Disease. St Louis, Missouri: Elsevier Saunders, 2005. 687p. 
TOPA, M.C.; ISEENSEE, K.; THOMPSON, G. Um caso de dermatofilose em bovino. Revista Portuguesa de Ciências Veterinárias, v.96, p.89-93, 2001.

TOWERSEY, L.; MARTINS, E.C.S.; LONDERO, A.T.; HAY, R.J.; SOARES FILHO, P.J.; TAKIYA, C.M.; MARTINS, C.C.; GOMPERTZ, O.F. Dermatophilus congolensis human infection. Journal of the American Academy of Dermatology, v.29, n.2, p.351-354, 1993.
ZARIA, L.T. Dermatophilus congolensis infection (dermatophilosis) in animals and man! An update. Comparative Immunology and Microbiology Infectious Diseases, v. 16, n.3, p.179-222, 1993.

ZASTEMPOWSKA, E.; LASSA, H. Genotypic characterization and evaluation of an antibiotic resistance of Trueperella pyogenes (Arcanobacterium pyogenes) isolated from milk of dairy cows with clinical mastitis. Veterinary Microbiology, v. 161, p. 153-158, 2012. 